\title{
Study on the Educational Function and Cultural Communication of Contemporary Museums
}

\author{
Shuyan Pei \\ School of Historical Culture and Tourism \\ Xi'an University \\ Xi'an, China 710065
}

\author{
Yuanyuan Wan \\ School of Historical Culture and Tourism \\ Xi'an University \\ Xi'an, China 710065
}

\begin{abstract}
As a treasure house of human material and nonmaterial civilization, the museum has a wealth of exhibits, and its main functions tend to be collection, display, protection and research. However, as an important social education institution, the museum has an important supplement and perfection for education. With the continuous development of museum culture and the introduction of relevant policies, the development direction of contemporary museums is no longer simply to display and collect cultural relics, but rather to serve the public and society, provide knowledge and education to the public, and guide the public to establish a correct view of history and values, and give full play to the educational functions of the museum.
\end{abstract}

Keywords-museum; education; cultural communication; social group; history

\section{INTRODUCTION}

China's definition of the museum is: institutions of collecting, reserving, researching, displaying, exhibiting cultural relics or specimens of related to revolutionary, historical, cultural, artistic, natural science, technology, etc. With the rapid development of society, the functionality of museums has gradually been extended. Therefore, the current understanding of Chinese museums can be further expanded to: an institution, building, place, or social public institution of cultural education to provide knowledge, education and appreciation to the public that can collect, reserve, display and study the physical objects representing nature and human cultural heritage, and classify those items that are scientific, historical or artistic.

The contemporary museum is a non-profit, permanent institution that is open to the public and provides services for social development with the aim of learning, education and entertainment. In the past year, the International Council of Museums (ICOM) invited members of the council and other relevant members to participate in to submit a proposal of "new definition of the museum", and set a new definition of museum at the 139th session held in Paris from July 21st to 22nd, 2019.

First, the museum is a space of democratization, inclusiveness, and multivariate equality for the development of a speculative dialogue between the tradition and the future. From the perspective of the museum itself, the collections displayed in the museum are historical relics produced by human society. Whether it is from ancient times, or modern times, it reflects the human society at that time, representing the productivity of society at that time and the status quo of society and class. From the perspective of the relationship between the museum and the present era, the museum serves as the "second classroom" for the education of the people. The people are the groups of direct audiences to understand ancient civilizations, promote culture, and enhance cognition through the museum. Secondly, museums should recognize and attempt to resolve current conflicts and challenges, preserve the specimens of cultural relics for the society, preserve diverse memories for future generations, and guarantee equal rights and access to inheritance for all. In addition, the museum is not for profit. The museum is a non-profit, permanent institution that serves society and its development and is open to the public. The term "non-profit" as used herein can be understood as "not a profit-only organization" or "a not-for-profit organization". The museum ticket sales are mainly to ensure the basic operation of the museum. Finally, museums should be participatory and transparent and work actively with different communities. It aims to collect, preserve, research, interpret, demonstrate and strengthen the understanding of the world for different groups, and contribute to human dignity, social justice, world equality and global well-being.

\section{The Educational Function of Museums}

The basic functions of the museum can be summarized as collection, research, and education, which reflect the main content of the museum's work. [1] As the material basis of all the activities of the museum, the collection is interdependent and complementary to the museum, and is not a "one or the other" relationship. Without a collection, there would be no museums. If there are no museums, those objects that are worthless and represent the development of human society will have no place to be stored. Therefore, collection is the primary and most basic function of the museum.

Collection alone is not enough, so there must be research and exhibition. The cultural relics that visitors often enter and see in the museum are the "exhibitions of exhibits" that have been exhibited to the world after they have been cleaned up and repaired. Most of the cultural relics in the museum are not exhibited, and more research and repair 
work is carried out in the research repair area or stored in the warehouse. Taking the Shaanxi History Museum as an example, it is the first large-scale modern national-level museum in China, with a total of 1.17795 million pieces of cultural relics (groups). However, the actual number of cultural relics exhibited is far less than that. An independent cultural relic is just an unearthed artifact before it is positioned or determined. The real value of cultural relics lies in the historical significance and social needs behind it. Only the research of relevant industry workers can reveal the scientific, artistic, and historical value of cultural relics.

Museum education is based on collection and research. It is reasonable that the museum is called the "second classroom". As a medium of knowledge transfer, it is based on contemporary society and meets the public's pursuit of history, technology, nature, art and so on. Thanks to the economic and social development, the number of museums in China has increased significantly. According to the National Museum Directory from 2012 to 2016, the number of museums was 3,866 in 2012, reaching 4,826 in 2016 and an increase of $24.8 \%$ in five years. [2] Visiting the museum has become a new way of leisure and learning for the Chinese. On February 9, 2015, the State Council promulgated the "Museum Regulations", of which Article 35 clearly stipulates: "The administrative department of education under the State Council shall, in conjunction with the State Administration of Cultural Relics, formulate policy measures for the use of museum resources for education, teaching and social practice activities." [3] Driven by a series of related policies, Chinese museums have placed more emphasis on education, from the traditional "relics warehouse" to "social education institutions". For a long time, the museum has a treasure house of collecting and displaying human and non-material civilizations. It has rich exhibits. Its main functions tend to be collection, display, protection and research, but the museum, as an important social education institution, has an important complement and improvement effect on education. With the continuous development of museum culture and the introduction of relevant policies, as well as the importance of society to the educational functions of museums, the development direction of contemporary museums is no longer simply to display and collect cultural relics. Instead, it is more inclined to serve the public and society, provide knowledge and education to the public, guide the public to establish correct historical views and values, and give full play to the educational function of museums.

\section{COMMUNICATION OF EARLY CHILDHOOD CULTURE AND EDUCATION}

The role of early childhood education in museums is mainly reflected in parent-child activities. Parent-child activities are an active way of life and family education advocated by modern society. They are not only conducive to promoting family harmony, but also have an inestimable social education role for the overall development of young children. Nowadays, the family tour in social institutions is mostly based on the nature of tourism. How to use the museum to make weekend trips and holiday trips into a family tour that integrates tourism and education is a primary concern of museum educators.

Museum early childhood education integrates enjoyment and interactive participation into activities or courses, guiding children to open their minds to acquire knowledge through their own actions and solve problems, growing up in activities. Taking the museum course "Tang Dynasty Culture and Ancient Pottery" developed by Xi'an University of Arts and Sciences "Museum Education and Civility Etiquette Curriculum Development Team" as an example, it is divided into three parts: PPT overview, costume display and handson molding. The science teachers' 15-20 minutes teaching combined with the PPT can make the children have a general understanding of the Tang Dynasty, have a certain interest in the production and life of the Tang Dynasty, and learn about Han and Tang costumes and eating habits. The science teachers and the assistant teachers can cooperate to display the Tang Dynasty costumes, and let the children go on stage to dress up and experience the ancient Tang costume culture. Then the children will cooperate with the group to complete the pottery figurine of their own group in about 30 minutes, and make clothes and draw expressions for the pottery figurine. This link can truly stimulate the children's enthusiasm for participation and cultivate their initiative in learning and exploration. Finally, the teachers' questioning link enables the children to further consolidate the knowledge points, which make the learning content digested and absorbed in the classroom, and achieve the timely and accurate delivery of learning effects and the cultivation of interests.

In the museum education of children, parents are also important participants and partners in educational activities. "The Education Law of the People's Republic of China" clearly proposes to establish and improve a lifelong education system. Family education is at the starting point of lifelong education for one person. Parents' behaviors and actions will directly affect children for their whole life. The habits cultivated in childhood can be accompanied by the entire children's life. [4] For children in the middle and large classes of kindergartens and lower grades of primary schools, knowledge range of target audience is relatively small. Many knowledge points cannot be understood simply by teaching. Guiding and developing interests should be taken as priority in educational activities. Parents must not only give children the necessary support and help during the activities, but also participate in the activities and experience the joy of growing together with the children. This is also the unique charm of museum education, which fosters the interest of children and promotes parent-child relationships that benefit families.

\section{COMMUNICATION OF TEENAGERS' CUlTuRAL EDUCATION}

As far as the current situation of youth education is concerned, students are affected by the examination-oriented education. The education is fixed mainly as school education, supplementing by institutional education. However, with the deepening of the concept of "lifelong education", the unique status of museum education has gradually emerged, and it has been widely recognized by the public as a special way of 
education, which has expanded the connotation of education. Compared with the traditional curriculum for daily learning of young people, museum education provides different ways for young students to discuss and think, so that students' ideological cognition can be edified under the new model education. Although exam-oriented education is still dominant in China, museum education still has to rely on school education in many cases. However, by integrating museum education resources to meet the requirements of school education, a strong mutual aid relationship between museum education and school education is established, which will help to enhance the awareness and range of target audience of museum education.

The syllabus and system of museum education and traditional curriculum are completely different. Museum education is based on the study of objects and has unlimited openness. During the specific practice of the museum courses, some parents have raised the question: the role of the students in the museum courses is only to broaden the knowledge. According to the discipline, it only adds some historical knowledge. If the children do not study liberal arts in the future, or their work in the future is not based on humanities and social sciences, will there be any "practical" gains? Aside from the traditional educational thoughts, museum education has a good training effect on the cultivation of teenager's learning literacy. A variety of thoughts can be triggered by a heritage: students will want to know "what is it?" What is it used for? Why make this artifact? Why preserve it? What does it mean in the museum? "The answers to these questions involve a wide range of disciplines including archaeology, history, physics, chemistry, folklore, art, geography, etc., which can make use of the interactivity of various disciplines to promote students' new understanding. This is why it is more appropriate for museum educators to choose an extended, immersive, research-based educational model in which the educational environment in this mode is more liberal, oriented to interest, curiosity and problems, rather than following specific textbooks or lesson plans. The educational effect is better reflected through revealing the multi-level meaning of cultural relics through interaction and interaction.

At the same time, museum education is not limited to traditional exam-oriented education, and it is also the cultivation of students' behavioral literacy. At present, the performance of Chinese people in public places such as museums is embarrassing. Although more and more parents and teachers have begun to notice the use of social education resources to carry out educational activities, the educational resources of the museum are still not fully utilized. Therefore, improving students' civilized etiquette and behavioral literacy should also become an important task of museum social education. In the process of organizing activities, it is necessary to actively guide students to visit and study in a museum in a civilized and polite manner, and gradually cultivate students' civilized etiquette and behavioral literacy.

\section{The Ways of Middle-Aged AND Elderly PeOPle PARTICIPATING IN MUSEUM EDUCATION AND THE ROLE OF CUlTuRAl COMMUNICATION}

As everyone knows, museum education is an important way of adult education, and it is an important way for people to complete "lifelong learning" and "full study." How to carry out the museum education of middle-aged and elderly people is a topic worth exploring. The core content of museum education is to improve the social attributes of museums through the analysis of its educational functions, to meet the concept of lifelong learning for all walks of life, and to realize the stable innovation of museum educational function and methods. [5] The construction of the museum faces the entire society, and different age groups have different needs for the museum. In order to enable the middle-aged group to make full use of the educational resources of the museum and better realize the educational function of the museum, the museum needs to be built more comprehensively to meet these needs, and the middle-aged and elderly groups need more diverse ways to receive museum education.

\section{A. Designing Targeted Exhibitions}

Undoubtedly, the exhibition of museums is a direct way to influence and educate the visitors. The museum education is carried out through the exhibition of cultural relics, as well as conveying cultural connotations of the museum, with a rigorous logical structure and a complete exhibition layout. Therefore, when the museum carries out display design, it is necessary to consider the different needs of different age groups. For the middle-aged and elderly people, it will be a must to be close to their social life and the memory of the times. This approach provides an intuitive and diverse learning model for middle-aged groups. Organizing a variety of special exhibitions is an effective educational approach. The special exhibition can make full use of the rich collection resources in the museum, and display certain themes through certain designs, so as to attract more audiences and better achieve the purpose of museum education.

\section{B. E-education}

E-education is also one of the ways to spread the museum culture. E-education refers to the use of modern educational technology such as projection, slides, movies, television, and computers to transmit educational information and design, research, and manage this process. In the contemporary era, e-education has been widely used in museum education. Whether it is a variety of multimedia interactive equipment in the museum or the dissemination of museum knowledge outside the museum on the online media, the flexibility of museum education is fully utilized to enable learning, which makes education simple and diverse. Taking the documentary "Masters in the Forbidden City" as an example, it records the repair process of the rare and rare cultural relics of the Forbidden City and the life story of the repairers that a big craze on the Internet has made more people love and start to learn about artifacts and museums. This is a successful example of education through 
[4] Liu Jingbo, Thoughts on the Timeliness and Design of Museums in Parent-child Education Activities [M]. Leading - Action and Thinking of Museum Education, Sept. 2017, version 1, p244. (in Chinese)

and outside the museum.

\section{Participating in Interactive Activities of the Museum}

Organizing various interactive activities is a very popular educational method in recent years. The museum fully mobilizes the resources in the museum. The cultural relics are no longer "dignified" exhibits in the showcase. It is a kind of object that can interact with the audience and resonate, allowing the visitors to "participate" into the museum and make the museum "interesting". The Shaanxi History Museum presents the cultural relics repair laboratory in front of the public, allowing the public to face the restoration process of cultural relics; the National Museum of China has hosted Guobo expert appraisal and social welfare activities, linking the museum to the visitors' life; Beijing Lu Xun Museum held series of activities called "Walk into the Museum and Enter Lu Xun", which made the visitors experience the activities of print rubbing, portrait stone rubbing, wire-bound book DIY, silk screen printing, etc., to better understand $\mathrm{Lu}$ Xun... When the elderly participate in such activities, they will also feel the enjoyment, and appreciate the charm of cultural relics and museums, which will realize the purpose of education.

\section{CONCLUSION}

Through the theoretical research and practice of museum education, it can be seen that museum education is aimed at not only the unilateral knowledge expansion of a single group, but also the cultural literacy cultivation and national spiritual inheritance of the whole society. The cultural communication role of the museum cannot be underestimated. Whether it is the cultivation of children's learning interest, the development of teenager's learning, or the historical and cultural recollection of the middle-aged and elderly people, cultural relics and museums carry positive connotations, which profoundly affect the way of life and thinking of the public. The arrival of the $4 \mathrm{G}$ era has enabled people to access information from pictures to video, which has greatly improved people's information acquisition and knowledge output efficiency. All walks of life have benefited and developed rapidly, and the museum industry is also in the list. With the further development of high technology, China will usher in the $5 \mathrm{G}$ era. How can museums use information technology to firmly grasp the dividends brought by the $5 \mathrm{G}$ era, so as to maximize the practical functions and cultural communication of museum education, is a new direction for museum workers to continue to explore and research.

\section{REFERENCES}

[1] Wang Hongjun, The Basic of Chinese Museology [M]. Shanghai Classics Publishing House, 2001. (in Chinese)

[2] Wang Wen, China Enters the Era of "All People's Anxiety" [J]. Guangdong Civil Administration, 2011. (in Chinese)

[3] State Council of the People's Republic of China, Museum Regulations (State Council Order No. 659) [Z]. 2015-1-14. (in Chinese)

[5] Dou Xiaoyu, Exploring the Educational Function and Educational Methods of Museums [J]. Global Market Information Guide, 2017, 5. (in Chinese) 